PENELITIAN

\title{
Pengaruh Pemberian Minuman Karbohidrat Preoperasi Terhadap Kadar Glukosa Darah Dan Tingkat Kecemasan Pasien Yang Akan Menjalani Operasi
}

\section{The Effect Of Preoperative Carbohydrate Drink On Blood Glucose And Anxiety}

Ahmad Feza Fadhlurrahman $\bowtie *$ *, Djudjuk Rahmad Basuki*, Isngadi*, Frilya Rachma

* Bagian Anestesiologi dan Terapi Intensif, Fakultas Kedokteran Universitas Brawijaya/ RSUD Dr.

Saiful Anwar, Malang

**Bagian Psikiatri, Fakultas Kedokteran Universitas Brawijaya/ RSUD Dr. Saiful Anwar, Malang

\begin{abstract}
Background. Surgery would cause a stress response. Stress response can arise as psychological, anesthesia or surgical stress. Patients undergoing elective surgery often experience preoperative anxiety, a psychological stress situation involving the activation of neuroendocrine and inflammation systems. The anxiety experienced by patients can pose significant problems in management of patients. Hemodynamic instability, autonomic and endocrine stimulation may worsen metabolic condition caused by surgery.
\end{abstract}

Objective. To determine the effect of carbohydrate drink on patients' preoperative blood glucose and anxiety levels.

Methods. This was a double blind randomized clinical experimental study. Samples were taken by consecutive sampling of 30 patients with ASA I and II, then divided into two groups: a control group that underwent night fasting and the treatment group that received $400 \mathrm{ml}$ of 12,5\% carbohydrate drink 2-3 hours preoperatively. Assessment of the anxiety levels and measurement of blood glucose levels were done in the premedication room. The data were analysed with path analysis.

Results. Carbohydrate drink caused a significant decrease $(p<0,05)$ in the patients' preoperative anxiety levels with a path coefficient of -0,771. The changes of blood glucose levels did not significantly $(p>0,05)$ decrease the patients' preoperative anxiety levels with a path coefficient of -0,173.

Conclusion. Carbohydrate drink has a significant effect on the decrease of patients' preoperative anxiety levels. While the changes in blood glucose levels do not have a significant effect on the decrease of patients' preoperative anxiety levels and do not increase the effect of carbohydrate drink in decreasing anxiety levels.

Keywords. Carbohydrate drink, blood glucose level, preoperative anxiety level.

\section{ABSTRAK}

Latar belakang. Tindakan operasi akan menyebabkan terjadinya suatu respon stres. 
Stres yang timbul dapat merupakan stres psikologi, stres anestesi dan stres pembedahan. Pasien yang akan menjalani operasi elektif seringkali mengalami kecemasan preoperasi, suatu keadaan stres psikologi yang dapat mengaktivasi sistem neuroendokrin dan inflamasi. Kecemasan yang dialami pasien dapat menimbulkan masalah yang signifikan dalam manajemen pasien. Ketidakstabilan hemodinamik, stimulasi otonom dan endokrin dapat memperburuk kondisi metabolik akibat operasi.

Tujuan. Untuk mengetahui pengaruh minuman karbohidrat terhadap kadar glukosa darah dan tingkat kecemasan preoperasi pasien.

Metode. Jenis penelitian adalah uji klinis eksperimental acak tersamar ganda. Sampel diambil secara consecutive sampling sebanyak 30 pasien dengan ASA I dan II, kemudian dibagi menjadi dua kelompok yaitu kelompok kontrol yang menjalani puasa malam hari dan kelompok perlakuan yang mendapatkan minuman karbohidrat $12,5 \%$ $400 \mathrm{ml}$ 2-3 jam preoperasi. Penilaian tingkat kecemasan dan pengukuran kadar glukosa darah dilakukan di ruang premedikasi kamar operasi. Data yang diperoleh akan dianalisis menggunakan analisa jalur.

Hasil. Minuman karbohidrat memiliki pengaruh yang signfikan $(\mathrm{p}<0,05)$ terhadap penurunan tingkat kecemasan preoperasi pasien dengan koefisien jalur sebesar $-0,771$. Pengaruh perubahan kadar glukosa darah tidak menunjukkan hasil yang signifikan $(p>0,05)$ terhadap penurunan tingkat kecemasan preoperasi pasien dengan koefisien jalur sebesar $-0,173$.

Kesimpulan. Pemberian minuman karbohidrat menurunkan tingkat kecemasan preoperasi pasien secara signifikan. Sedangkan perubahan kadar glukosa darah tidak

\section{PENDAHULUAN}

Pasien yang akan menjalani operasi elektif seringkali mengalami kecemasan preoperasi, suatu keadaan stres psikologis yang melibatkan aktivasi dari axis hipotalamus-pituitari dan sitokin-sitokin., ${ }^{1,2}$ Kecemasan (anxiety) adalah suatu perasaan tidak menyenangkan yang terdiri atas respons -respons psikofisiologis terhadap antipasi bahaya yang tidak riil atau yang terbayangkan, secara nyata disebabkan oleh konflik intrapsikis yang tidak diketahui. Peristiwaperistiwa yang terjadi dalam kehidupan dapat menjadi penyebab munculnya rasa cemas, salah satunya adalah operasi. Insiden kecemasan preoperasi berkisar antara 60\%-92\%. Sebagian besar pasien akan mengalami kecemasan dalam masa tunggu menjelang operasi. ${ }^{3,4}$

Sebelum operasi, pasien akan dipersiapkan terlebih dahulu dengan cara puasa. Puasa preoperasi menjadi bagian dalam lingkup patient safety, dan durasinya memegang peranan yang penting. Literatur terbaru mengenai puasa preoperasi merekomendasikan puasa 2 jam untuk cairan bening dan 6 jam untuk makanan padat pada kebanyakan pasien bedah. Sementara pada beberapa institusi kesehatan, 
pasien masih tetap menjalankan puasa selama 12 sampai 16 jam. $^{5}$

Puasa yang terlalu lama dapat menyebabkan beberapa efek samping dan mempengaruhi kondisi fisik dan psikis pasien, seperti mudah tersinggung, pusing, dehidrasi, muntah, hipovolemi dan hipoglikemi. Selama puasa pasien dapat merasa tidak nyaman dengan keluhan utama yang dirasakan berupa haus, lapar dan cemas. ${ }^{6}$ Kondisi tersebut akan menambah kecemasan preoperasi pasien. Kecemasan yang dialami pasien dapat menimbulkan masalah yang signifikan dalam manajemen pasien. Ketidakstabilan hemodinamik, stimulasi otonom dan endokrin dapat memperburuk kondisi metabolik akibat operasi. $^{3}$

Efek negatif pada fisik dan psikis, berupa peningkatan jalur katabolik dan rasa tidak nyaman, dari puasa preoperasi memunculkan beberapa penelitian yang hasil akhirnya menunjukkan pasien dalam kondisi 'diberi makan' (fed state) preoperasi mengalami perbaikan kondisi., ${ }^{7,8}$ Pemberian minuman karbohidrat dapat menurunkan tingkat kecemasan preoperasi pasien pada penelitian yang menggunakan VAS (Visual Analogue Scale) sebagai alat ukur. The European Society of Clinical Nutrition and Metabolism merekomendasikan pemberian minuman karbohidrat 2 jam preoperasi dengan salah satu keuntungan berupa penurunan rasa cemas pasien. $^{5}$

\section{METODE}

Penelitian ini merupakan uji klinis acak tersamar ganda (randomized double blind clinical trial) yang melibatkan 30 pasien di RSUD dr Saiful Anwar Malang dan dilakukan di ruang premedikasi bedah sentral serta ruang rawat inap.

Kriteria inklusi yaitu pasien yang menjalani operasi elektif bedah onkologi minor di instalasi bedah sentral RSUD dr Saiful Anwar Malang dengan kategori status fisik ASA I-II, usia 40-60 tahun, tingkat pendidikan minimal SMP, status fisik ASA I-II, BMI 20-30 kg/M2, bersedia menjadi peserta penelitian dan menandatangani informed consent. Kriteria eksklusi adalah pasien dengan penyakit Diabetes Mellitus, pasien dengan gangguan pasase usus, pasien dengan riwayat penyakit psikiatri dalam 6 bulan terakhir, pasien dengan terapi anti konvulsan, anti ansietas dan anti psikotik, dan pasien menolak.

Sampel dibagi secara acak dalam dua kelompok: kelompok kontrol yang menjalani puasa malam hari dan kelompok perlakuan yang mendapatkan minuman karbohidrat 12,5\% $400 \mathrm{ml} 2$ 3 jam preoperasi.

Pengukuran kadar glukosa darah dan penilaian tingkat kecemasan pasien dilakukan di ruang premedikasi kamar operasi RSUD dr Saiful Anwar Malang. Kadar glukosa darah diukur dengan bantuan laboratorium sentral RSUD dr Saiful Anwar Malang dan tingkat kecemasan pasien dinilai menggunakan Hamilton Anxiety Rating 
Scale.

Analisa statistik pada penelitian ini menggunakan analisis jalur (path analysis).

\section{HASIL}

Karakteristik data dari sampel penelitian ini dapat dilihat pada tabel 1 . Pasien dibagi menjadi dua kelompok, kelompok kontrol dan kelompok perlakuan dengan minuman karbohidrat. Karakteristik yang dikaji adalah usia, indek massa tubuh (IMT), status ASA dan jenis kelamin. Hasil pengujian dari data demografi pasien pada kelompok kontrol dan kelompok perlakuan dengan minuman karbohidrat memiliki nilai signifikansi yang lebih besar dari nilai alpha 5\% ( $>00,05)$. Hal tersebut menunjukkan bahwa untuk faktor karakteristik sampel yang diuji pada kedua perlakuan tidak memiliki perbedaan signifikan yang dapat mempengaruhi variabel tergantung berupa tingkat kecemasan pada penelitian ini dan dinilai homogen.

Gambar 1 menunjukkan hasil data yang diperoleh selama penelitian, yakni data kadar glukosa darah dan tingkat kecemasan pada kelompok kontrol dan kelompok perlakuan. ratarata kadar glukosa darah pada kelompok kontrol sebesar 87,5 sedangkan pada kelompok perlakuan 95,3. Rata-rata tingkat kecemasan pada kelompok kontrol sebesar 5,33 sedangkan pada kelompok perlakuan sebesar 2,06.

Setelah karakteristik demografi pasien homogen, selanjutnya dilakukan uji regresi pada masing-masing variabel seperti ditunjukkan gambar 2. Tabel 2 menunjukkan hasil uji regresi, secara simultan variabel minuman karbohidrat (X) dan glukosa darah (Y) memiliki kontribusi sebesar $70,4 \%$ dalam menjelaskan perubahan yang terjadi pada variabel tingkat kecemasan (Z), sedangkan sisanya sebesar 29,6\% dijelaskan oleh variabel lain diluar model $\left(\epsilon_{2}\right)$. Kontribusi yang dihasilkan oleh variabel minuman karbohidrat $(\mathrm{X})$ dalam menjelaskan perubahan yang terjadi pada variabel glukosa darah (Y) sebesar $8,7 \%$ sedangkan sisanya sebesar 91,3 dijelaskan oleh variabel lain diluar model $\left(\epsilon_{1}\right)$.

Pada uji t/parsial terlihat bahwa variabel minuman karbohidrat (X) memiliki pengaruh yang signifikan terhadap tingkat kecemasan $(\mathrm{Z})$ dengan nilai signifikansi lebih kecil dari a 5\% yaitu 0,000 , namun tidak signifikan terhadap variabel glukosa darah (Y) dengan nilai signifikansi 0,113 . Begitu pula dengan pengaruh variabel glukosa darah (Y) terhadap tingkat kecemasan (Z) yang menunjukkan hasil tidak signifikan dengan nilai 0,126 .

Pengaruh langsung variabel minuman karbohidrat (X) terhadap variabel tingkat kecemasan $(Z)$ adalah sebesar 0,771. Sedangkan pengaruh tidak langsung melalui variabel glukosa darah (Y) tidak dihitung karena dari uji sub struktural pengaruh variabel glukosa darah (Y) terhadap tingkat kecemasan (Z) tidak signifikan. Sehingga, pengaruh total minuman karbohidrat $(\mathrm{X})$ terhadap tingkat 
kecemasan (Z) memiliki nilai yang sama dengan pengaruh langsungnya, yaitu 0,771 atau $78 \%$.

\section{PEMBAHASAN}

Pasien yang akan menjalani operasi elektif seringkali mengalami kecemasan preoperasi, yakni suatu keadaan stres psikologis yang melibatkan aktivasi dari axis hipotalamus-pituitari dan sitokinsitokin. ${ }^{1}$ Kecemasan yang dialami pasien dapat menimbulkan masalah yang signifikan dalam manajemen pasien. Ketidakstabilan hemodinamik, stimulasi otonom dan endokrin dapat memperburuk kondisi metabolik akibat operasi. $^{3}$

Penanganan kecemasan preoperasi pada umumnya dilakukan dengan cara farmakologis dan non farmakologis. Penelitian ini bertujuan untuk mengetahui pengaruh pemberian minuman karbohidrat terhadap tingkat kecemasan pasien baik secara langsung maupun tidak langsung melalui peningkatan kadar glukosa darah.

Dari total sampel sejumlah 30 orang, setelah uji analisa jalur, didapatkan bahwa minuman karbohidrat memiliki pengaruh yang signifikan terhadap tingkat kecemasan pasien preoperasi. Seperti yang dapat dilihat pada tabel 2, minuman karbohidrat memliki koefisien jalur $(\rho)$ sebesar -0,771 dengan tingkat signifikansi 0,00 . Tanda (-) menunjukkan pengaruh minuman karbohidrat menurunkan tingkat kecemasan yang dialami pasien preoperasi.

Hasil penelitian ini sama dengan penelitian yang dilakukan oleh Hausel et al (2009) tentang pengaruh minuman karbohidrat terhadap rasa haus, lapar, cemas, depresi, nyeri, kelelahan, kelemahan, ketidakmampuan berkonsentrasi dan rasa mual. Dari penelitian tersebut didapatkan pasien dengan minuman karbohidrat memiliki tingkat kecemasan yang lebih rendah dibandingkan dengan pasien yang menjalani puasa konvensional. ${ }^{9}$ Penelitian tersebut menggunakan metode VAS (Visual Analogue Scale) untuk menilai tingkat kecemasan, sedangkan pada penelitian ini tingkat kecemasan dinilai menggunakan skala HARS (Hamilton Anxiety Rating Scale) yang memiliki validitas dan reliabilitas cukup tinggi untuk melakukan pengukuran kecemasan pada suatu clinical trial. Skala HARS merupakan pengukuran kecemasan yang didasarkan pada munculnya gejala pada individu yang mengalami kecemasan. Dari data sampel penelitian, minuman karbohidrat mampu menurunkan total gejala kecemasan pada kelompok perlakuan secara signifikan.

Penurunan tingkat kecemasan pasien preoperasi juga dapat disebabkan karena rasa nyaman yang dirasakan oleh pasien setelah pemberian minuman karbohidrat. Penelitian Helminen, et al (2010) menyebutkan terjadi penurunan rasa haus dan lapar yang signifikan pada kelompok pasien yang mendapatkan minuman karbohidrat dibandingkan 
dengan kelompok pasien yang menjalani puasa konvensional. ${ }^{10}$ Rasa haus dan lapar merupakan keluhan utama ketidaknyamanan pasien yang menjalani puasa preoperasi. ${ }^{6}$

Secara teori, pemberian minuman karbohidrat sejumlah 50 gr dapat merangsang sekresi insulin. Insulin dapat memodulasi sistem dopaminergik dan serotonergik yang memiliki peran penting dalam kondisi depresi. Peningkatan kadar insulin akan memberikan efek positif (peningkatan) dari kadar serotonin yang bekerja sebagai mood booster bagi pasien. ${ }^{11}$ Pada level mekanik, insulin menurunkan aktifitas enzim monoamin oxidase, yang berperan dalam pemecahan serotonin dan dopamin sehingga meningkatkan aktifitas dari sistem-sistem tersebut. ${ }^{12}$

Pada penelitian ini, perubahan kadar glukosa darah tidak memberikan pengaruh yang signifikan terhadap perubahan tingkat kecemasan. Koefisien jalur yang dihasilkan sebesar -0,173 dengan tingkat signifikansi sebesar 0,126. Bila dianalisa, hal ini lebih disebabkan karena pada kelompok perlakuan, pengambilan sampel darah vena dilakukan pada 2-3 jam setelah pemberian minuman karbohidrat. Sedangkan pada waktu tersebut, kadar glukosa darah sudah turun kembali pada rentang basal setelah sempat meningkat untuk merangsang sekresi insulin pada awal pemberian minuman karbohidrat. Kondisi ini menyebabkan uji regresi kadar glukosa darah tidak signifikan terhadap perubahan tingkat kecemasan maupun dari pengaruh minuman karbohidrat.

Pada kelompok perlakuan, minuman karbohidrat yang dikonsumsi akan dipecah oleh enzim-enzim pencernaan menjadi bentuk monosakarida. Monosakarida kemudian diabsorbsi oleh brush border pada usus halus (duodenum dan bagian proksimal ileum) dan kemudian memasuki sirkulasi tubuh. ${ }^{1,13}$ Kondisi hiperglikemi pasca pemberian asupan karbohidrat dicegah melalui sekresi insulin. ${ }^{1}$

Insulin akan merangsang peningkatan uptake glukosa darah kedalam sel otot skeletal, jaringan adiposa dan sel otot jantung. ${ }^{14}$ Pada orang normal, konsentrasi glukosa darah dikontrol dalam rentang yang cukup sempit, biasanya antara 80 dan $90 \mathrm{mg} / 100 \mathrm{ml}$ darah dalam keadaan puasa setiap pagi sebelum sarapan. Konsentrasi ini meningkat menjadi 120 sampai $140 \mathrm{mg} / 100 \mathrm{ml}$ selama sekitar satu jam pertama setelah makan, namun sistem umpan balik untuk kontrol glukosa darah mengembalikan kadar glukosa ke rentang normal dengan cepat, biasanya dalam 2 jam setelah absorpsi karbohidrat terakhir. ${ }^{15}$

Dari penelitian oleh Yagmurdur et al (2011), kadar glukosa darah dan insulin mengalami peningkatan setelah pemberian minuman karbohidrat preoperasi. Kadar insulin akan mencapai level puncak pada menit ke40 setelah pemberian minuman karbohidrat. Penelitian tersebut menunjukkan bahwa pemberian 
minuman karbohidrat $12,5 \%$ sebanyak $400 \mathrm{ml}$ preoperasi dapat meningkatkan kadar insulin serum pada tingkat yang mampu merubah kondisi pasien yang sebelumnya "fasted state" menjadi "fed state" sebelum operasi. ${ }^{16}$

Pada kelompok kontrol, puasa preoperasi mulai malam hari akan mengakibatkan habisnya persediaan glukosa darah. ${ }^{5}$ Namun, tubuh memiliki respon adaptif yang mampu membuatnya tetap berfungsi walaupun dengan kondisi kekurangan masukan nutrisi. Selama 24 sampai 48 jam pemberhentian masukan nutrisi, penyimpanan glikogen akan dipecah (glikogenolosis) untuk menyediakan glukosa bagi jaringan. Glikogenolisis diperantai oleh adanya peningkatan rasio glukagon:insulin (peningkatan glukagon dan penurunan insulin) yang nantinya akan meningkatkan produksi glukosa endogen (glukoneogenesis). ${ }^{1}$ Puasa mulai malam hari akan menghambat sekresi insulin dan meningkatkan sistem glikolisis pada pagi hari saat operasi. Kondisi ini akan meningkatkan kadar glukosa darah tubuh. ${ }^{16}$

Penilaian tingkat kecemasan menggunakan Hamilton Anxiety Rating Scale. Data numerik dari skala tersebut dinilai berdasarkan jumlah gejala yang timbul akibat stres psikologis yang dialami oleh pasien. Pada penelitian ini didapatkan hasil nilai tertinggi pada kelompok kontrol dan perlakuan masing-masing sebesar 8 dan 3 .
Rendahnya nilai tertinggi pada kedua kelompok, terutama kelompok kontrol, disebabkan tingkat stres psikologi pada pasien preoperasi sederhana lebih rendah dibandingkan tingkat stres operasi pada pasien preoperasi besar. Disamping itu, motivasi pada sebagian besar pasien preoperasi sederhana adalah untuk mencari penyembuhan dan menghilangkan penyakit yang diderita dengan kondisi status fisik yang masih relatif baik, sehingga tingkat kecemasan yang dialami lebih rendah.

\section{SIMPULAN}

Pemberian minuman karbohidrat menurunkan tingkat kecemasan preoperasi pasien secara signifikan. Sedangkan perubahan kadar glukosa darah tidak memiliki pengaruh yang signifikan terhadap penurunan tingkat kecemasan preoperasi pasien dan tidak menambah pengaruh penurunan tingkat kecemasan oleh minuman karbohidrat. 
Tabel 1. Data Karakteristik Subyek

\begin{tabular}{|c|c|c|c|}
\hline Variabel & $\begin{array}{l}\text { Kelompok } \\
\text { Kontrol }(\mathrm{n}=15)\end{array}$ & $\begin{array}{l}\text { Kelompok } \\
\text { Perlakuan } \\
(n=15)\end{array}$ & $\begin{array}{l}\text { Hasil Uji Beda } \\
\text { (nilai p) }\end{array}$ \\
\hline Usia (tahun) & $\begin{array}{l}\text { Rerata } 49,26 \pm \\
5,79\end{array}$ & $\begin{array}{l}\text { Rerata } 47,73 \pm \\
5,95\end{array}$ & $0,481^{\mathrm{a}}$ \\
\hline $\operatorname{IMT}(\mathrm{kg} / \mathrm{m} 2)$ & $\begin{array}{l}\text { Rerata } 23,52 \pm \\
2,63\end{array}$ & $\begin{array}{l}\text { Rerata } 24,75 \pm \\
2,44\end{array}$ & $0,206^{\mathrm{b}}$ \\
\hline ASA & & & $0,291^{b}$ \\
\hline I & 1 & 3 & \\
\hline II & 14 & 12 & \\
\hline Jenis Kelamin & & & $0,417^{b}$ \\
\hline Laki-Laki & 3 & 5 & \\
\hline Perempuan & a 12 & 10 & \\
\hline
\end{tabular}

Tabel 2. Hasil Uji Regresi

\begin{tabular}{cccc}
\hline Variabel & Koef. Beta & R Square & Signifikansi \\
\hline $\mathrm{X} \rightarrow \mathrm{Z}$ & $-0,771(\rho \mathrm{ZX})$ & 0,704 & 0,00 \\
\hline $\mathrm{Y} \rightarrow \mathrm{Z}$ & $-0,173(\rho \mathrm{ZY})$ & & 0,126 \\
\hline $\mathrm{X} \rightarrow \mathrm{Y}$ & $0,296(\rho \mathrm{YX})$ & 0,087 & 0,113 \\
\hline
\end{tabular}




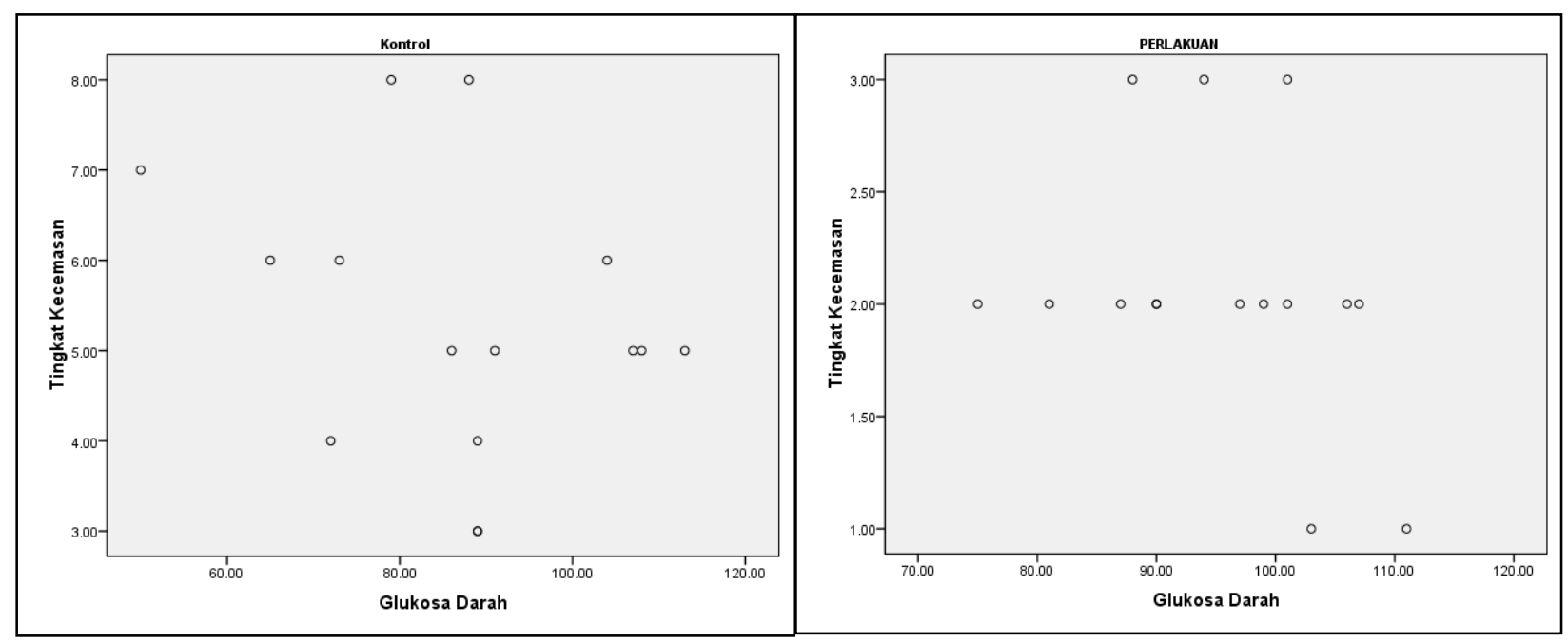

\begin{tabular}{lcccc}
\hline \multirow{2}{*}{ Variabel } & \multicolumn{2}{c}{ Kelompok Kontrol } & \multicolumn{2}{c}{ Kelompok Perlakuan } \\
\cline { 2 - 5 } & Mean & SD & Mean & SD \\
\hline Glukosa Darah & 87,5 & $\pm 1,83$ & 95,3 & $\pm 1,01$ \\
\hline Tingkat & 5,33 & $\pm 1,54$ & 2,06 & $\pm 0,59$ \\
Kecemasan & & & & \\
\hline
\end{tabular}

Gambar 1. Data Kadar Glukosa Darah dan Tingkat Kecemasan

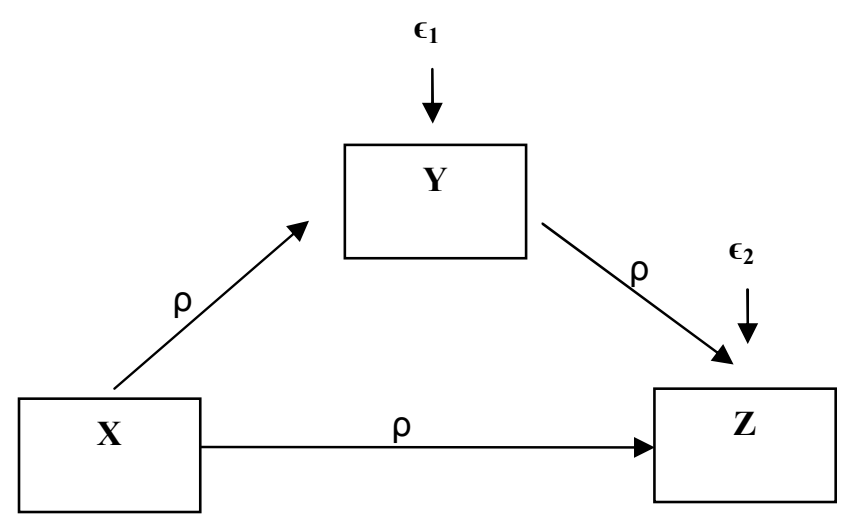

Gambar 2. Model Analisa Jalur

Keterangan:

X: Minuman Karbohidrat

Y: Glukosa Darah

Z: Tingkat Kecemasan

$\rho:$ Koefisien Jalur 


\section{DAFTAR PUSTAKA}

1. Miller, RD,. Gastrointestinal Physiology and Pathophysiology. Miller's Anesthesia, 8th edition. 2015. p 505507.

2. Alfanti, EF., Budiono, U., Arifin, J. Pengaruh infus dekstrosa $2,5 \% \mathrm{nacl}$ $0,45 \%$ terhadap kadar glukosa darah perioperatif pada pasien pediatri. Jurnal Anestesiologi Indonesia. 2012. Volume IV, Nomor 2.

3. Matthias, AT. Preoperative anxiety in surgical patients-experience of a single unit. University Surgical Unit. The National Hospital of Sri Lanka. 2012. Sri Lanka. Acta Anaesthesiologica Taiwanica 50 3e6. Elsevier

4. Nigussie, S., Belachew T., Wolancho W. Predictors of preoperative anxiety among surgical patients in jimma university specialized teaching hospital, south western ethiopia. Department Of Nursing, College Of Medical And Health Sciences, Samara University, Samara, Ethiopia. 2014. BMC Surgery, 14:67

5. Gul, A., Andsoy, I., Ustundag, H., Ozkaya. Assessment of preoperative fasting time in elective general surgery. 2013. JMHM Vol 1 Issue 1.

6. Imbelloni, LE., Pombo, IA., Borges, G. Reduced fasting time improves comfort and satisfaction of elderly patients undergoing anesthesia for hip fracture. Faculdade de Medicina Nova Esperanca . Brazil . Rev Bras Anestesiol. 2015;65(2):117---123

7. Ljungqvist $\mathrm{O}$, Nygren $\mathrm{J}$, Thorell A. Modulation of Post-Operative Insulin Resistance by Pre-Operative Carbohydrate Loading. Proceedings of the Nutrition Society. 2002. 61:329-335,
8. Tran, S. Preoperative Carbohydrate Loading In Patients Undergoing Coronary Artery Bypass Or Spinal Surgery. Thesis. 2009. Graduate Department of Nutritional Sciences University of Toronto.

9. Yilmaz, N. Çekmen N., Bilgin F., Erten E., Özhan MÖ., Coşar A. Preoperative carbohydrate nutrition reduces postoperative nausea and vomiting compared to preoperative fasting. 2013. J Res Med Sci;18:827-32.

10.Bilku, DK., Dennison AR., Hall TC., Metcalfe MS., Garcea G. Role of preoperative carbohydrate loading: a systematic review. University Hospitals of Leicester NHS Trust, UK. 2014. Ann $R$ Coll Surg Engl 2014; 96: 15-22

11.Wurtman, R., J. Brain serotonin, carbohydrate-craving, obesity and depression.. Department of brain and cognitive sciences and clinical research center. Massachusetts Institute of Technology. 1995. Obesity research vol. 3

12.Kleinridders, A., et al. Insulin action in brain regulates systemic metabolism and brain function. Joslin Diabetes Center and Department of Medicine. Harvard Medical School. Boston. Diabetes 2014;63:2232-2243

13.Morgan, GE., Mikhail MS. Clinical Aneshesiology. Fifth Edition. 2013. McGraw Hill Education.

14.Barash PG., et al. Clinical Anesthesia, 6th Edition. Lippincott Williams \& Wilkins. 2009. Philadelphia.

15.Guyton, A.C and Hall, J.E. Textbook of Medical Physiology, 11th ed. 2006. Philadelphia, PA, USA: Elsevier Saunders.

16. Yagmurdur, H., et al. The effects of carbohydrate-rich drink on perioperative 